\title{
THE INTERNAL CAREER ORIENTATION OF PERMANENT AND CONTRACTING INFORMATION TECHNOLOGY STAFF
}

\author{
HILDA HAVRAN \\ DELÉNE VISSER \\ FREDDIE CROUS \\ Programme in Industrial Psychology \\ Department of Human Resource Management \\ Rand Afrikaans University
}

\begin{abstract}
The primary aim of the study was to investigate the relationship between types of employment (permanent or contracting) for two variables: flow and career success orientation in an information technology environment. The study was performed in a sub-division of a large telecommunications company that focuses on software development and implementation. Two questionnaires measuring flow and career success orientation, were administered to groups of 150 permanent and 150 contracting staff respectively. Factor analyses indicated that the career success orientation questionnaire measured two dimensions labeled as 'work focus' and 'self focus', and the flow questionnaire measured 'enjoyment' and 'control of consciousness'. Contracting and permanent employees were compared with regard to the four dimensions and it was found that contract workers experienced their work more optimally than the permanent workers did, because they obtained higher scores on the 'control of consciousness scale'.
\end{abstract}

\section{OPSOMMING}

Die primêre doel van die ondersoek was om die verwantskap tussen tipes indiensneming (permanent en kontraktering) te ondersoek vir twee veranderlikes: vloei en beroepsuksesoriëntasie in 'n inligtingstegnologieomgewing. Die ondersoek is uitgevoer in 'n onderafdeling van 'n groot telekommunikasiemaatskappy wat fokus op programmatuurontwikkeling en -implementering. Twee vraelyste wat vloei en beroepsuksesoriëntasie meet, is toegepas op 150 permanente werknemers en 150 kontrakteurs. Faktorontledings het aangedui dat die beroepsuksesoriënteringsvraelys twee dimensies gemeet het, naamlik 'werkfokus' en 'selffokus'. Die vloei-vraelys het 'werksgenot' en 'bewustsheidbeheer' gemeet. Kontrakteurs en permanente werknemers is met mekaar vergelyk in terme van die vier dimensies en die uitslae van die bewustheidsbeheerskaal het aangedui dat kontrakteurs hul werk meer optimaal ervaar in teenstelling met permanente werkers.

In the 1970's the world of work began to change. The meaning of job, work and career began to take on different nuances as the large employment organisation, with its promise of stability and steady upward progression, began to disappear (Handy, 1985).

With continued waves of restructuring, mergers and acquisitions, part time workers would increasingly be called in to meet the demands of ever changing work conditions (Hall, 1996). It followed logically that more flexible staffing options would become the norm for the future and that the use of contractors for non-core activities would allow permanent staff to focus on value adding work for the organisation.

The nature of the workforce was changing and companies were beginning to embrace the principals of the "shamrock" organisation (Handy, 1989). Like the small shamrock plant, with its leaf made up of three separate leaflets, the new organisation's workforce is comprised of three different, yet unified parts.

The first leaf is comprised of core staff, or what Handy (1989) referred to as the professional core. They are vital for the continued existence of the organisation and are the technicians, managers and other professionals who are committed to the company and strongly identify with it. In turn they are highly valued.

The second leaf is made up of contractors, or what Handy (1989) called the contractual fringe. These are people with special skills who are paid for the results they produce, not the time spent on the job. The work they do is not part of the core competence of the organisation and it is work that can be done faster, cheaper and better by someone who is specialised and who works autonomously.

The third leaf is what Handy (1989) referred to as the flexible labour force. These are part-time or temporary workers who

Requests for copies should be addressed to: D Visser, Department of Human

Resource Management, RAU University, PO Box 524, Auckland Park, 0006 supplement the organisation. Their affiliation is more towards having a job than towards having a career. Handy (1989) later added a fourth leaf. This consists of the customers whose role in the organisation's value chain is becoming increasingly active.

The "shamrock" organisation has become a reality. However, the move towards the utilisation of a new workforce is evolving faster in certain sectors of the economy than in others. Bridges (1995) highlights how these changes are especially noticeable in the IT sector, where the dynamic and flexible nature of the workforce mirrors the ever changing, fluid and innovative nature of the industry. The Gartner Group (1999) supports this view and states that in five years from now over $50 \%$ of all IT staff will be comprised of contracting staff.

The present study was performed in an IT environment in order to examine how the subjective experience of career differs between permanent and contracting staff, whether they are part of the flexible labour force or the contractual fringe.

\section{Contractors}

The main defining characteristic of contractors, also sometimes referred to as part-time or contingent workers, is that they give their services for a certain period of time until a deadline has been met (Hamlyn, 1999). They are professionals or entrepreneurs who choose where they want to work and use their skills to gain monetary reward (Carroll, 1998). In the case of contractors in the IT industry, these rewards are often lucrative depending on the competence of the contractor (Carroll, 1998). Contractors in turn value the flexibility that the job offers them (Hippel, 1997). They typically enjoy a challenge and are independent people capable of managing each new assignment given to them (Goodwin, 1998).

Contractors need to manage their own skills levels. This can be a challenge in itself. Most companies are not prepared to train 
contractors and contractors are reluctant to devote time to training that could otherwise be spent on earning an income (Hippel, 1997). However, contractors' services are only valued for as long as their skills are up to date and useful. Continuous skills development is therefore essential to avoid skill stagnation and maintain marketability.

Clearly, traditional views of career, where one's career is defined by a steady progression up a corporate ladder, no longer apply here. Within the changing needs of the new organisation, the flexible workforce is required to refocus its view of what a career is (Hall, 1996).

But it is not only contractors that are reviewing career notions. Within organisations, where structures, reporting lines and business foci are in a state of flux, it is becoming increasingly important for individuals who form part of the "professional core" to relook what having a "career" means (Blau, 1988)

One perspective on how to define a career is to view it as an individual's subjective opinion of working life and the role that he/she plays within it. This is the "internal" career as described by Schein and Van Maanen (1977). Currently this career concept is being incorporated into the notion of the "protean career", that is, a process that the individual is managing and that is redefined according to the changing needs of that person (Shreuder \& Theron, 1997). Individuals and not organisations are responsible for individuals' career development. This requires of individuals to assess and re-assess their strengths and weaknesses on an ongoing basis, a process that requires self-reflection and places increased reliance on individuals' inner compasses to guide them forward in career choices. Besides skills development, individuals have final control over pursuing careers that foster personal growth and satisfaction (Van den Berg, 2002). Increasingly people are striving towards freedom and growth in the work that they do and the need to experience work in an optimal way.

The degree to which both contracting staff and permanent workers experience their work optimally can be expressed using the psychological term of flow (Csikszentmihalyi, 1988).

\section{Flow}

Flow has become an important term in the field of intrinsic motivation. It is a description of an experience that is autotelic or rewarding in and of itself. It was first described by Csikszentmihalyi (1988) who observed the phenomenon through his interests in watching artists painting purely for the sake of the activity itself.

People describe the feeling of flow as being deeply satisfying beyond even just enjoyment. It is characterised by a feeling of loss of consciousness and freedom where all sense of time is lost. People in a state of flow are so involved in the activity that they are unaware of themselves as being separate from it (Csikszentmihalyi, 1988).

Flow is not the result of striving towards a goal or a promise of reward at the end of the activity (Csikszentmihalyi, 1988), but it is enhanced when clear goals are established, feedback is received from the task, concentration is high and control of the activity is anticipated and derived (Csikszentmihalyi, 1988).

Two aspects are important in the experience of flow: Firstly, the degree to which the activity is challenging and secondly, the degree to which the individual has the skills to perform the task (Csikszentmihalyi, 1988). A feeling of flow will only occur where there is a balance between the perceived challenge of the situation and the degree to which the person feels sufficiently skilled to respond to it (Csikszentmihalyi, 1988). It is not only the balance of skills and challenge that is important. The individual must perceive both the level of skill required as well as the challenge of the task as high. Where the level of skill and challenge is in balance but is low, apathy is more likely to be an outcome than flow. Similarly where the challenge of the task is too high, anxiety will result. These three outcomes, that is, apathy, anxiety and optimal experience, are described in the three-channel model devised by Csikszentmihalyi (1988). Massimini and Carli (1988) have since extended this model to an 8-channel model of flow. This model describes further permutations that can occur in the interaction between skills and challenges.

The balance between skill and challenge is a dynamic process (Csikszentmihalyi, 1990). As a person develops the skill, it is easy for the person to slip into boredom because the challenge has been overcome and no further learning is taking place. This explains why people, having experienced the positive feelings of flow, will search for both new opportunities and novel ways of expanding their skills in order to replicate the sensation (Csikszentmihalyi, 1990).

Csikszentmihalyi and Csikszentmihalyi (1988) have reported that the measure of flow is an important one in organisations. A work environment often provides the ideal environment for an experience of flow in that it is usually structured to allow for goals to be set, it allows for clear feedback, it encourages concentration and in most situations links skills and challenges. It is not surprising that flow has been found to link with job satisfaction (Carli, Della Fave \& Massimini, 1988; Han, 1988). The degree to which this happens is dependent on the nature of the job. Where the job entails high levels of challenge and the utilisation of advanced skills, a sense of well being will be enhanced by feelings of flow through which the person continuously learns, discovers and grows (Csikszentmihalyi, 1988; Anderson, Crous \& Schepers, 1996).

The matching of skills and challenge is ever present in the field of IT. The rapid development of technology and the shortening of product life cycles ensure that new challenges will always have to be met with some skills needing to be sharpened and others learnt. Certainly, the degree to which IT staff experience flow will be determined by whether or not they perceive challenge and whether or not they posses the necessary skills to do the work.

Individuals who have chosen non-traditional career paths, such as the career paths taken by contractors, tend to develop strong professional identities (Peiperl \& Barite, 1997). They are, therefore, highly committed to continuously seeking new growth opportunities (Bedeian, Kemery \& Pizzolatto, 1991). The ongoing development of skills and seeking out of new challenges would seem to form a large part of the contractor's career growth. This dynamic interplay of skills and challenges as well as the fact that contractors have more freedom in their work to monitor and track their own progress and learning, creates optimal conditions for the experience flow.

The need for freedom or liberty is seen to be an important need for contractors (Schein, 1978) and it is likely that the degree to which this need is met in the work they do, will define career success for them as a group. Permanent workers on the other hand, will probably value security and upward progression in defining career success.

Career success according to Derr (1986) means being able to live out the subjective and personal values that one believes in as well as the success of the contribution one makes to the world of work. More and more, in one's course or progress through life that makes up a career, work is becoming an expression of one's humanity (Handy, 1985). Different aspects of work mean success for different people and in light of this, Derr (1989) has defined five career success orientations.

\section{Career success orientation}

Based on work done by Schein and Driver, Derr (1986) proposed five different career success orientations. These define an 
individual's internal career view or map that drives career choices (Derr \& Laurent, 1989). They are determined by the person's unique plans and hopes and they answer the question: "What does the employee really want from a career?" Derr's (1986) theory is clearly focused on an internal career orientation and reinforces the notion of the protean career in the sense that the career is controlled by the person and is not driven by external factors. Career is viewed from an individual's subjective view of his or her work life and the role that he or she plays within it. The five success orientations as Derr (1986) defines them are as follows:

Getting ahead - this is the more traditional view of career; here the upwardly mobile individual strives to move up through the ranks of the organisation.

Getting secure - this person aims to achieve job security, stable circumstances and respect and recognition, success is defined by the context of the work rather than the content.

Getting free - this may refer to independent workers who aim to achieve maximum control over their work. Like "getting secure" people they are more concerned with the context of the work. For them work must be challenging and interesting but their own personal liberty is core.

Getting high - the aim of these people is to do exciting and interesting work. They often require freedom too, but unlike "getting free" individuals, they are prepared to sacrifice freedom for the work. They are "endlessly fascinated by the content of their work" (Derr 1986, p123). Some companies have found that the best way of getting value from this type of employee is to hire them on a part-time or contracting basis.

Getting balanced - this is achieving a balance between career, relationships and self-development so that work can remain meaningful.

These career success orientations are hypothesised to differ for contractors and permanent IT staff. Reich and Kaarst-Brown (1999) report that technical orientation, lifestyle balance, autonomy, and challenge are predominating orientations amongst IT professionals. They love the work and they love the challenge. Technical employees typically define their careers according to either an IT specialisation or according to an affiliation with a company (Reich \& Kaarst-Brown, 1999).

It is therefore expected that contractors who experience work optimally, will define career success independently of the organisation and will have a career success map oriented to getting free or getting high. In contrast, permanent staff whose careers are defined within organisational contexts will be more inclined towards getting secure and getting ahead. Consequently the primary purpose of this study will be to investigate the relationship between flow, and career orientation in permanent and contracting staff in an IT environment. The hypotheses stated below are the logical consequences of Derr's (1986) and Csikszentmihalyi's (1990) theories applied to permanent and contracting staff in an IT context.

\section{Hypothesis 1:}

Contractors will experience significantly higher levels of flow than permanent employees. The nature of the work performed by contractors is more conducive to the experience of flow than for permanent staff because permanent staff members are more restricted in terms of freedom. Contractors are more at liberty to seek out new challenges and enhance their skills, whilst also being required to do so to sustain their relevance to the organisation.

\section{Hypothesis 2:}

Permanent and contracting staff will display significantly different orientations towards career success as defined by Derr (1986). a) Contractors who experience work optimally (as determined by flow) will tend to obtain high scores on the "getting free" and "getting high" career success orientations.

b) Permanent staff who experience work optimally (as determined by flow) will be inclined to obtain high scores on the "getting ahead and "getting secure" career success orientations.

This study will add to the body of research that attempts to understand how the new work force has changed its views of career management. Company structures no longer define or enable career success, especially not for contractors whose career paths are particularly at odds with existing organisational frameworks (Von Hippel et al., 1997). Increasingly however, organisations are realising the importance of understanding their employees. This enables them to provide the conditions for a competent, motivated and effective workforce. Knowledge, therefore, of how the views of contractors differ from those of permanent staff will promote sound management of contractors by both organisations and vendors who hire out their services (De Voe, 1999)

\section{METHOD}

\section{Participants}

The sample was drawn from the Information Technology Services Group of a large telecommunications company. A sub-division of the organisation, where a large number of contractors were working, was targeted. This environment is largely project driven and as a result is comprised of a core group of permanent professional staff, whereas contractors are employed to supplement operations. It is argued that in this sub-division the groups of contractors and permanent staff are similar, because both are engaged in the development, testing, integration and implementation of IT products and solutions. The total population was made up of 538 employees. This population consisted of 196 contractors and 346 permanent staff.

Two stratified samples of 150 staff members each were randomly drawn from the contractor and permanent staff groups respectively. These samples represented all functions and cultural groups. Of the total sample, 203 participants returned usable questionnaires. This was comprised of 94 questionnaires from contractors and 109 from permanent staff.

The two groups were closely matched with regards to their job functions, age, gender and marital status. The average age for the total sample was 34 years, ranging from 22 to 66 years $(\mathrm{SD}=$ $8.30)$ and the majority were women (62\%). Most of them (66\%) were married or living with a partner. When examining the contractor and permanent groups separately, it was found that each consisted of $41 \%$ programmers, $14 \%$ project managers, $5 \%$ project co-ordinators and $4 \%$ team leaders. Differences between the groups occurred regarding the numbers of line managers and analysts. The permanent sample consisted of $10 \%$ line managers, whereas in the contracting group there were none. Analysts made up $26 \%$ of the permanent sample and $36 \%$ of the contracting group.

The tenure at the company ranged from 6 months to 29.42 years for permanent staff with a mean of 6.42 years $(S D=7.53)$. The mean period of the contract for contractors was 1.92 years $(\mathrm{SD}=$ 2.79). The period of time that contractors had been working as contractors ranged from 3 months to 21 years with a mean of 4.89 years $(\mathrm{SD}=3.80)$. Most contractors $(90 \%)$ had worked as permanent staff previously for an average period of 10 years $(\mathrm{M}$ $=10.08$ ) and their tenure as permanent staff ranged from 3 months to 30 years $(S D=8.62)$.

\section{Measuring Instruments}

Flow Experience Survey (FES)

Based on research performed by Csikszentmihalyi and 
Csikszentmihalyi (1988) and Csikszentmihalyi (1990), Anderson, Crous and Schepers (1996) developed a 56-item questionnaire to measure flow experience. In compiling their Flow Experience Survey (FES), Csikszentmihalyi's Flow Questionnaire (1993) was used as a source. The instrument consisted of two scales, namely enjoyment obtained from the activity and control of consciousness involved in the activity (Anderson, Crous \& Schepers, 1996). The first scale, enjoyment, had an internal consistency reliability of 0.95 , and the second, control of consciousness, had a reliability coefficient of 0.83 (Anderson et al., 1996). To increase the content validity of the instrument, which had only 6 items loading on the second scale, Percival, Crous and Schepers (2001) added 13 items. The amended version of the FES was used in the present study. Every item is presented on a sevenpoint scale, allowing for a range of responses from unfavourable to extremely favourable.

\section{Career Success Map Questionnaire (CSM)}

Career orientation was measured using the Career Success Map (CSM) originally developed by Derr (1986) and adapted by Roslee, Crous and Schepers (1998) to form a 58-item questionnaire where each item is presented on a seven-point scale. The responses ranged from "little or no extent" to "a very great extent".

Until 1998 no information had been available on its psychometric properties prompting Roslee, Crous and Schepers (1998) to perform a factor and item analysis of the instrument as part of a study to determine the internal career orientation of the type A personality. The present study aimed to replicate Roslee et al.'s (1998) findings in order to test the relevance of Derr's theory in the South African context. Roslee et al. (1998) found that a factor analysis of the items yielded four scales that are aligned with Derr's original thinking. These were: freedom seekers, comfort seekers, equilibrium seekers and competition seekers.

\section{Procedure}

The two questionnaires and a biographical questionnaire were administered to the sample during group sessions. As the business language of the organisation is English, the questionnaire and instructions were presented in English only. In the sessions the researcher explained the rationale for the study and addressed any questions from the group. Individuals were given a week within which to complete the questionnaires that were returned via their line managers to the researcher.

\section{RESULTS}

The first step in the analysis of the data was to explore the psychometric properties of the two questionnaires used in the study, namely the CSM and the FES. This was regarded as an appropriate step, because little information exists for the CSM and the FES is still in its developmental stage. The results are discussed separately for each instrument below.

\section{Career Success Map Questionnaire (CSM)}

The 58 items of the CSM were subjected to an exploratory factor analysis. Before doing this, it was necessary to determine whether the sample was adequate and to ascertain whether there was sufficient justification to perform a factor analysis. The Kaiser-Meyer-Olkin measure of sampling adequacy (MSA) was equal to 0.79 . This is adequate for factor analysis. The result of the Bartlett test of sphericity yielded a statistically significant chi-square $\left[\chi^{2}\right.$ $(1653)=4987.60, \rho<0.001]$

The participants' scores on the 58 items were subjected to a principal axis factor analysis. Fifteen factors emerged, accounting for $67.39 \%$ of the total variance. The factor matrix was rotated to simple structure by means of a varimax rotation.
For every participant, a score was calculated on each of the fifteen factors by adding together only item scores that had high loadings on the factor in question. These scores were then subjected to a second factor analysis.

Diagnostic tests of the intercorrelation matrix of the 15 derived factors yielded an anti-image correlation for one of the factors that did not meet the suggested criterion value of 0.60 (Hair, Anderson, Tatham \& Black, 1998). This factor was removed before performing the second-order factor analysis, thereby removing two items from the original questionnaire.

The remaining data was again analysed to determine whether there was sufficient justification to perform a factor analysis. The Kaiser-Meyer-Olkin measure of sampling adequacy was now 0.82 , indicating that the sample was adequate. The Bartlett test of sphericity yielded a statistically significant approximate chisquare $\left[\chi^{2}(66)=647.75, \rho<0.001\right]$.

The principal axis factor analysis resulted in the extraction of three factors accounting for $55.41 \%$ of the total variance. Factor three was not adequately determined, because only two variables had substantial loadings on it. It was subsequently decided to extract two factors only. These were rotated by means of the direct oblimin procedure.

The two factors that emerged accounted for $45.86 \%$ of the total variation and the correlation between the factors was equal to 0.45 . The factor pattern matrix is reported in Table 1 .

TABLE 1

FACTOR PATTERN MATRIX OF THE CAREER SuCCESS MAP QUESTIONNAIRE

\begin{tabular}{lccc}
\hline & Factor $\mathbf{1}$ & Factor 2 & $\mathbf{h}^{2}$ \\
\hline CSM 02 & 0.63 & -0.16 & 0.51 \\
CSM 12 & 0.61 & 0.25 & 0.28 \\
CSM 05 & 0.60 & 0.03 & 0.40 \\
CSM 04 & 0.55 & -0.19 & 0.42 \\
CSM 01 & 0.52 & 0.03 & 0.39 \\
CSM 08 & 0.51 & -0.25 & 0.77 \\
CSM 07 & 0.50 & -0.23 & 0.37 \\
CSM 11 & 0.27 & 0.13 & 0.21 \\
CSM 06 & 0.02 & -0.77 & 0.58 \\
CSM 09 & -0.02 & -0.60 & 0.38 \\
CSM 03 & 0.23 & -0.40 & 0.36 \\
CSM 10 & 0.21 & -0.32 & 0.28 \\
\hline
\end{tabular}

The items contained in each of the factors were studied and the two factors were labelled Work Focus and Self Focus. The internal consistency reliabilities are shown in Table 2 together with the number of items from the original CSM that comprise the new scales. In summary the new scales can be described as follows:

Work Focus: From the items it is clear that this scale describes a career orientation centred on achievement in a work context. The focus is on the active, energetic achievement of goals, either for the sake of stability or for the sake of upward progression. The contents describe the ideal participant in the new world of work, that is, someone who is dynamic, flexible, accountable, competitive and involved. The focus for the individual is "work is important".

Self Focus: The items in this scale clearly describe an orientation towards the self, the family and the need to be "one's own person". Personal goals and independence are uppermost with the emphasis shifting away from external constraints and goals. The focus for the individual is "I am important". 
TABLE 2

CAREer Success SCAles AS DEFINED by DERR'S Dimensions WITH ASSOCIATED CRONBACH ALPHA INTERNAL CONSISTENCY RELIABILITIES

\begin{tabular}{lll}
\hline Scale & Items & Reliability coefficient \\
\hline Work focus & 9 Getting ahead & 0.90 \\
& 4 Getting balanced & \\
& 4 Getting free & \\
11 Getting high & \\
& 11 Getting secure & \\
& 1 Getting ahead & 0.81 \\
Self focus & 8 Getting balanced & \\
& 1 Getting free & \\
\hline
\end{tabular}

Flow Experience Survey (FES)

As with the CSM, an exploratory factor analysis was performed on the FES. This was done after an initial analysis to determine whether the sample was adequate or not and to ascertain whether it was appropriate to continue with the factor analysis.

The Kaiser-Meyer-Olkin Measure of sampling adequacy (MSA) was equal to 0.88 . This indicated that the sample merits further analysis (Hair et al., 1998). The result of the Bartlett test of sphericity indicated a chi-square that was significant $\left[\chi^{2}(2346)\right.$ $=8083.57, \rho<0.001]$.

However, the intercorrelations between items yielded antiimage correlations for three items that were deemed inappropriate for factor analysis. These three items were removed before continuing with the first order factor analysis. Again diagnostic tests where performed, the Kaiser-MeyerOlkin measure of sampling adequacy (MSA) became 0.89. The Bartlett test of sphericity again showed a significant chisquare $\left[\chi^{2}(2145)=7762.10, \rho<0.001\right]$ and provided sufficient proof that significant correlations exist between at least some of the variables.

The participants' scores on the remaining 66 items were subjected to a principal axis factor analysis. This yielded sixteen factors, accounting for $70.31 \%$ of the total variance. The factor matrix was rotated to a simple structure by means of a varimax rotation.

A score for each of the sixteen factors was calculated for each respondent and these scores were intercorrelated. The intercorrelation matrix revealed that one of the factors did not meet the suggested criterion value for the MSA of 0.60. This factor contained only one item and it was subsequently removed before a second factor analysis was performed. The Kaiser-MeyerOlkin measure of sampling adequacy (MSA) was equal to 0.89 , indicating that the sample was adequate. The Bartlett test of sphericity yielded a statistically significant approximate chisquare $\left[\chi^{2}(91)=1232.90, \rho<0.001\right]$.

Three factors were extracted describing $60.64 \%$ of the total variance. The factor pattern matrix appears in Table 3. Factor 3 did not represent any substantial loadings and was therefore omitted. The correlation between the resulting two factors is equal to 0.50 . The reliability was equal to 0.92 for Factor 1 and 0.94 for Factor 2.

The contents of the items in each scale were studied. The first scale had 26 items loading on it. These describe a sense of achievement and enjoyment at finding the job challenging, interesting and meaningful. The second, with 39 items, focuses clearly on the total immersion and absorption in the work to the exclusion of all else. It points to a balancing of skills and talents to match the requirements of the job, and describes a sense of coping and feeling good. These scales support previous research performed using this questionnaire (Percival, Crous \& Schepers, 2001) and a previous study performed by Anderson et al. (1996). In addition they support what Csikszentmihaly (1992) wrote about the concept of enjoyment and control of consciousness. The scales were therefore identified as they had been in previous studies as:

Factor 1 - Enjoyment

Factor 2 - Control of Consciousness

TABLE 3

Factor pattern matrix of the Flow Experience Survey

\begin{tabular}{lcccc}
\hline & Factor 1 & Factor 2 & Factor 3 & $\mathbf{h}^{\mathbf{2}}$ \\
\hline FES 02 & 0.87 & -0.08 & -0.19 & 0.73 \\
FES 15 & 0.78 & -0.03 & -0.06 & 0.58 \\
FES 04 & 0.77 & -0.07 & 0.10 & 0.56 \\
FES 07 & 0.72 & 0.02 & 0.09 & 0.55 \\
FES 05 & 0.64 & 0.24 & -0.17 & 0.63 \\
FES 12 & 0.27 & 0.09 & 0.21 & 0.15 \\
FES 10 & -0.14 & 0.67 & 0.04 & 0.37 \\
FES 06 & 0.20 & 0.61 & 0.30 & 0.59 \\
FES 01 & 0.34 & 0.54 & -0.40 & 0.74 \\
FES 09 & -0.03 & 0.52 & 0.00 & 0.25 \\
FES 03 & 0.45 & 0.51 & 0.25 & 0.74 \\
FES 13 & 0.02 & 0.50 & -0.14 & 0.29 \\
FES 08 & 0.30 & 0.47 & 0.09 & 0.45 \\
FES 11 & 0.16 & 0.43 & -0.34 & 0.41 \\
\hline
\end{tabular}

In order to determine if there were significant differences between contractors and permanent staff with regards to flow and career success orientation, the variables were subjected to a oneway Multivariate Analysis of Variance (MANOVA). Hotellings' $\mathrm{T}^{2}$ was equal to 0.05 with an associated $\mathrm{F}(4,198)=2.24, \mathrm{p}=0.066, \eta^{2}=0.04$. This revealed that no significant differences were evident between the groups. However, Tabachnick and Fidell (1996) explain that univariate $\mathrm{F}$ can be more powerful than multivariate F. Due to the fact that the exact $p$ value was close to 0,05 , it was decided to proceed with oneway analyses of variance (ANOVA) to determine if there were differences between the two groups with regards to flow and career success orientation. This revealed a statistically significant difference between contractors and permanent workers on the second flow factor, control of consciousness. The mean for contractors was higher than the mean for permanent staff. It can be concluded that contractors as a group experience a significantly higher degree of flow with regards to control of consciousness. These findings partially support the first hypothesis. The means and standard deviations of participants' scores on each of the two career success scales and on the two flow scales are presented in Table 4. The ANOVA results appear in Table 5.

The intercorrelation matrix of the emergent scales is presented in Table 6 . It shows that significant correlations exist between Work Focus and each of the flow scales. Work Focus is also correlated significantly with Self Focus. The factor analysis performed on the CSM revealed that the original categories as stipulated by Derr (1986) were not found in this sample. Instead two distinct orientations towards career success emerged. There is no theoretical basis to expect that there would be differences between contract workers and permanent staff who experience work optimally (as measured by flow) on either Work Focus or on Self Focus. The second hypothesis could, therefore, not be investigated. 
TABLE 4

DESCRIPTIVE STATISTICS INDICATING THE MEANS AND STANDARD DEVIATIONS FOR EACH SCALE

\begin{tabular}{llcc}
\hline & Employment status & M & SD \\
\hline Work Focus & Permanent & 5.66 & 0.53 \\
& Contractor & 5.69 & 0.54 \\
& Total & 5.68 & 0.53 \\
Self Focus & Permanent & 5.40 & 0.59 \\
& Contractor & 5.31 & 0.68 \\
Total & 5.36 & 0.63 \\
& Permanent & 4.59 & 0.88 \\
Coyment & Total & 4.67 & 0.82 \\
Control of consciousness & Permanent & 4.63 & 0.85 \\
& Contractor & 5.02 & 0.73 \\
& Total & 5.25 & 0.70 \\
& & 5.13 & 0.72 \\
\hline
\end{tabular}

TABLE 5

SUMMARY TABLE OF ANALYSES OF VARIANCE (ANOVA) FOR THE TWO FLOW SCALES AND THE TWO CAREER SUCCESS ORIENTATION SCALES

\begin{tabular}{lccccccccc}
\hline & $\begin{array}{c}\text { Levene's test of } \\
\text { equality of error } \\
\text { variance }\end{array}$ & \multicolumn{3}{c}{ Tests of between-subjects effects } \\
& F & p & SS & df & MS & F & p & $\eta^{2}$ \\
\hline Work Focus & 0.08 & 0.779 & 0.05 & 1 & 0.05 & 0.18 & 0.668 & 0.00 \\
Self Focus & 1.32 & 0.252 & 0.38 & 1 & 0.38 & 0.97 & 0.326 & 0.01 \\
Enjoyment & 0.15 & 0.695 & 0.38 & 1 & 0.38 & 0.52 & 0.472 & 0.00 \\
$\begin{array}{l}\text { Control of } \\
\text { Consciousness }\end{array}$ & 0.00 & 0.991 & 2.76 & 1 & 2.76 & 5.41 & 0.021 & 0.03 \\
\hline
\end{tabular}

Hotellings' $\mathrm{T}^{2}=0.05$

$\mathrm{F}(4,198)=2.24, \mathrm{p}=0.066$

$\eta^{2}=0.043$

TABLE 6

INTERCORRELATION MATRIX OF THE FLOW AND CAREER SUCCESS ORIENTATION SCALES (P VALUES ARE INDICATED IN BRACKETS)

\begin{tabular}{lcccc}
\hline & Work Focus & Self Focus & $\begin{array}{c}\text { Enjoyment } \\
\text { consciousness }\end{array}$ & Control of \\
\hline Work Focus & 1.00 & $\begin{array}{c}0.51 \\
(0.001)\end{array}$ & $\begin{array}{c}0.30 \\
(0.001)\end{array}$ & $\begin{array}{c}0.48 \\
(0.001)\end{array}$ \\
Self Focus & 0.51 & 1.00 & -0.05 & 0.12 \\
& $(0.001)$ & & $(0.513)$ & $(0.094)$ \\
Enjoyment & 0.30 & -0.05 & 1.00 & 0.68 \\
& $(0.001)$ & $(0.513)$ & & $(0.001)$ \\
Control of & 0.48 & 0.12 & 0.68 & 1.00 \\
consciousness & $(0.001)$ & $(0.094)$ & $(0.001)$ & \\
\hline
\end{tabular}

\section{DISCUSSION}

The primary aim of the study was to investigate the relationship between types of employment (permanent or contracting) in an IT environment on two variables, flow and career orientation. It was shown that a statistically significant relation exists between contractors and permanent staff with regard to control of consciousness. This finding partially supported the hypothesis that contractors experience greater flow than permanent workers do.

The scale on which significance was obtained, control of consciousness, refers to an absorption in the task to the exclusion of all outside and even internal interference. It points to a balancing of skills and job requirements that engenders feelings of coping and it highlights feelings of worth that emanate from the work being done. This supports the view that the work context of contractors is more suitable for the experience of flow in the job. A possible reason for this could be that they have greater control over their work environments and are better positioned than their permanent counterparts to seek challenging assignments that match their skills. They are better able to commit fully to their tasks because they are not likely to be interrupted by aspects pertaining to the running of the organisation as permanent employees are.

In addition, the findings of this study reinforce previous findings pertaining to the psychometric properties of the FES Previous studies had found that the validity of the second scale was not optimal (Percival et al., 2000). This study appears to support the inclusion of two scales, the first focused on the challenge and enjoyment inherent in the job and the second focused on the ability to focus one's consciousness so fully on the task at hand that all other activities shift out of awareness.

The second hypothesis could not be examined because an exploratory factor analysis of the instrument revealed that only two factors could be extracted. These factors do not reflect the original categorisations of career success as set out by Derr (1986) and that he had intended to measure with the CSM. The two career orientations that emerged are nevertheless important as they highlight the current shifts in focus for careerists. Greenhaus, Callanan and Godshalk (2000) wrote that, "Career management in the 21st century will require new insights and strategies to manage not only one's career but one's overall life as well" (p15). For many individuals the choice is now one between work and family. Greenhaus et al. (2000) further wrote, "the 1990's will be remembered as the decade in which the management of work-family conflict and the achievement of a balanced life style became issues of national priority" (p7-8). The importance of striving towards work and family balance has produced a recent stream of research that was aimed at understanding what aspects are responsible for work-family conflict as people increasingly struggle to balance their work and family lives (Stoeva, Chiu \& Greenhaus, 2002).

The study confirms the view that the concept of career is being challenged by social and economic pressures that in turn affect the beliefs that individuals hold about themselves, the people around them and the world of work generally (Bruck, Allen \& Spector, 2002; Watson \& Stead, 1999). Work is not the only way in which individuals strive to find personal meaning. It raises the issue again of "what a career is" and returns us to previously popular definitions that align with how earlier career theorists (Schein, 1978) define career. This view is encapsulated in the Oxford English dictionary (1982) definition of career as a person's "course or progress through life or history" (p139).

Although most career theory is focused on the relationship between the individual and work, it is perhaps opportune again to consider how the interplay between individuals and their work defines career success. This is possibly the most natural outcome of the fact that the management of one's career has increasingly become an individual and not an organisational activity (Greenhaus et al., 2000). In fact, more and more, the responsibility rests with the individual to define and forge his or her own career paths within the ever-changing organisation. The contract to manage one's career is not with the organisation, but with oneself (Hall \& Mirvis, 1996). This is the protean career that Hardijzer (1999) defines as " a process which 
the person and not the organization is managing. The protean career is shaped more by the individual than by the organisation and may be redirected from time to time to meet the needs of the person" (Hardijzer, 1999, p46).

It is important too that organisations acknowledge the focus on individual responsibility and make allowances for the balancing of work and self. Realising this does not necessarily threaten the "upward mobility ethic"; instead it means aligning human resource systems and processes with a redefinition of the employee-employer relationship (Greenhaus et al., 2000). It places a different responsibility on organisations that, while they cannot offer security to their staff, still require high-quality, self-directed, performancedriven individuals to do the work. The new "contract" implies that organisations must provide working environments that assist in resolving work-life issues and that link to the heart of what it means to be human (Van den Berg, 2002). Du Rand (2002) maintains that current HR practices should move away from a need for efficiency and move towards embracing systems or processes that acknowledge individuals' needs to work in a meaningful way and that allows employees to pursue personal interests. Business must therefore respond to the need for personal growth.

A limitation of this study is that it could not delve deeper than the experience of flow in researching the expected differences that one would find between contractors and permanent staff on career success orientation. The reason could be the homogeneity of the two groups. Although the second group classified themselves as contractors, $90 \%$ had in fact been previously employed as permanent workers for an average period of ten years. The average number of years that the individuals had been working as contractors was five years, making it likely that the values and beliefs around career success were still closely aligned to those of permanent staff. Nevertheless, the study has relevance in the field of career psychology, because it supports a call that has recently been made for an overall conceptual framework of career counselling that better matches individuals to the type of career needed in the new world of work (Coetzee \& Schreuder, 2002).

As the world of work continues to evolve and the economic landscape in South Africa continues to change, it would be valuable to explore further what drives the new contingent work force. This is particularly the case in the IT environment where IT organisations face the challenge of finding better systems solutions faster while constraining costs in a turbulent local business environment (Rimmer, 2002).

\section{ACKNOWLEDGEMENT}

The authors would like to thank Janes du Toit and Riëtte Eiselen at the statistical consulting service of RAU for the efficient and professional service they provided for this research regarding the processing of the data.

\section{REFERENCES}

Anderson, D.R., Crous, F. \& Schepers, J.M. (1996). Flow and the quality of work life in a diverse workforce. Journal of Industrial Psychology, 22 (3), 13-20.

Bedeian, A.G., Kemery, E.R. \& Pizzolatto, A.B. (1991). Career commitment and expected utility of present job as predictors of turnover intentions and turnover behaviour. Journal of Vocational Behavior, 39, 331-343.

Blau, G.J. (1988). Further exploring the meaning and measurement of career commitment. Journal of Vocational Behavior, 32, 284-297.

Bridges, W. (1994). Jobshift. How to prosper in a workplace without jobs. London: Nicholas Brealey.
Bruck, C.S., Allen, T.D. \& Spector, P.E. (2002). The relationship between work-family conflict and job satisfaction: A finergrained analysis. Journal of Vocational Behavior, 60, 336-353.

Carli, M., Della Fave, A., \& Massimini, F. (1988). The quality of experience in the flow channels: Comparison of Italian and US based students. In Csikszentmihalyi, M. \& Csikszentmihalyi, I.S. (Eds) (1988). Optimal experience: Psychological studies of flow in consciousness. New York: Cambridge.

Carroll, C. (1998). When is a contractor not a contractor? Retrieved September 132000 from the World Wide Web: http:www.computingsa.co.za/compsaarchice/1998/10/12/ca reers/car04.htm.

Clarke, S.G. \& Haworth, J.T. (1994). 'Flow' experience in the daily lives of sixth-form college students. British Journal of Psychology, 85, 511-523.

Coetzee, M. \& Schreuder, A.M.G. (2002). The relationship between career patterns and personality types. South African Journal of Industrial Psychology, 28 (1), 55-59.

Csikszentmihalyi, M. \& Csikszentmihalyi, I.S. (Eds). (1988). Optimal experience: Psychological studies of flow in consciousness. New York: Cambridge.

Csikszentmihalyi, M. (1990). Flow: The psychology of optimal experience. New York: Harper Collins.

Csikszentmihalyi, M. (1992). Flow: The psychology of happiness. London: Rider.

De Voe, D. (1999). Managing the contract workforce. Retrieved September 132000 from the World Wide Web: http:www.computingsa.co.za/compsaarchice/1999/09/06/ca reers/car03.htm.

Derr, C.B. \& Laurent, A. (1989). The internal and external career: A theoretical and cross cultural perspective. In M.B. Arthur, D.T.Hall \& B.S. Lawrence (Eds). Handbook of Career Theory. Cambridge: Cambridge University Press.

Derr, C.B. (1986). Managing the new careerist. San Francisco: Jossey Bass.

Du Raan, J. (2002). Exploring the next frontier. People Dynamics, $20(4), 40$.

Greenhaus, J.H., Callahan, G.A. \& Godshalk, V.M. (2000). Career Management. Orlando: Harcourt College Publishers. Gartner Group. (2000). Who is the IT worker of the future? Retrieved January 26, 2001 from the World Wide Web: http:www.gartnertechwatch.com/gg/static/itjournal/trend.h tml.

Gallos, J. V. (1989). Exploring women's development: implications for career theory, practice, and research. In M.B. Arthur, D.T. Hall and B.S. Lawrence (Eds). Handbook of career theory. Cambridge: Cambridge University Press.

Goodwin, L. (1998). Contracting - what is it all about? Retrieved September 132000 from the World Wide Web: http:www.computingsa.co.za/compsaarchice/1998/04/20/ca reers/car08.htm.

Hair, J. F., Anderson, R.A, Tatham, R.L. \& Black, W.L. (1998). Multivariate data analysis ( $5^{\text {th }}$ ed.). New Jersey: Prentice Hall.

Hall, D.T. (1996). The career is dead - long live the career: a relationship approach to careers. San Francisco: Jossey-Bass.

Hardijzer C. (1999). Careers: Treading a tricky path within the changing world of work. People Dynamics, 17 (11), 42- 46.

Hamlyn, J. (1999). Companies move from contracting to permanent staff. Retrieved September 132000 from the World Wide Web: http:www.computingsa.co.za/ compsaarchice/1999/02/08/careers/car02.htm.

Handy, C. (1985). The future of work. A guide to a changing society. Oxford: Basil Blackwell.

Handy, C. (1989). The age of unreason. London: Arrow.

Massimini, F. \& Carli, M. (1988). The systematic assessment of flow in daily experience. In Csikszentmihalyi, M. Csikszentmihalyi, I.S.(Eds.) (1988). Optimal experience: Psychological studies of flow in consciousness. New York: Cambridge.

Nicholson, N. (1996). Career systems in crisis: change and opportunity in the Information age. The academy of Management Executive, 10 (4), 40-52. 
Omstein, S. \& and Isabella, L.A. (1993). Making sense of careers: a review 1989-1992. Journal of Management, 19 (2), 243-263.

Peiperl, M. \& Baruch, Y. (1997). Back to square zero: The post corporate career. Organisational Dynamics, 25 (4), 7-23.

Percival, G., Crous, F. \& Schepers, J.M. (2000). The capability of incumbents and the complexity of jobs performed as predictors of flow. Unpublished master's dissertation, Rand Afrikaans University, Johannesburg.

Reich, B. H. \& Kaarst-Brown, M.L. (1999). Seeding the line: Understanding the transition from IT to non IT careers. MIS Quarterly, 23 (3), 337-352.

Rimmer, I. (2002). Embrace your inner hun. People Dynamics, 20 (4), 40.

Roslee, G., Crous, F. \& Schepers, J.M. (1998). The internal career of the type A personality. Journal of Industrial Psychology, 20 (2), 39-42.

Schein, E.H., \& Van Maanen, J. (1977). Career development. In J.R. Hackman and J.L. Suttle (Eds.), Improving Life at work. Santa Monica: Goodyear.

Schein E. H. (1978). Career dynamics. Redding: Addison - Wesley.
Schreuder, A.M.G., \& Theron A.L. (1997). Careers. An organizational perspective. Cape Town: Juta.

Stead, G.B. \& Watson, M.B. (Eds.) (1999). Career psychology in the South African context. Pretoria: J.L. van Schaik.

Stoeva, A.Z., Chiu, R.K. \& Greenhaus, J. H. (2002). Negative affectivity, role stress, and work-family conflict. Journal of Vocational Behavior, 60, 1-16.

Tabachnick, B.G. \& Fidell, L.S. (1996). Using multivariate statistics. New York: Harper Collins.

Thomas, D. A. \& Alderfer, C. P. (1989). The influence of race on career dynamics: theory and research on minority career experiences. In M.B. Arthur, D.T.Hall \& B.S. Lawrence (Eds). Handbook of career theory. Cambridge: Cambridge University Press.

Van den Berg, I.J. (2002). The Protean career: Implications for human resource systems. Unpublished master's dissertation, Rand Afrikaans University, Johannesburg.

Von Hippel, C., Mangum, S.L., Greenberger, D.B., Heneman, R.L. \& Skoglind, D. (1997). Temporary employment: Can organisations and employees both win? The Academy of Management Executive, 11 (1), 93-105. 